\title{
The prevention of curcumin against rat liver mitochondrial swelling induced by tert-butylhydroperoxide
}

\author{
S. Susilowati, Frans D. Suyatna, A. Setiawati
}

\begin{abstract}
Abstrak
Penyakit hati merupakan masalah kesehatan yang sulit diobati. Adanya masalah dalam pengobatan penyakit ini sebagian disebabkan karena tidak tersedianya obat yang terbukti berkhasiat. Kurkumin, senyawa aktif dalam akar keluarga tanaman curcuma telah diteliti dalam berbagai peyakit termasuk penyakit hati. Efek terapi kurkumin diduga berdasarkan efek antioksidatifnya. Dalam penelitian ini, kami menyelidiki efek kurkumin terhadap swelling mitochondria yang diinduksi oleh tert-butilhidroperoksida (t-BuOOH) Mitokondria hati diisolasi secara homogen dari tikus Sprague-Dawley (relative specific activity suksinat dehidrogenase adalah $35.73 \pm 2.78$ ). Pemberian $90 \mu \mathrm{M}$-BuOOH menyebabkan swelling 2 fase yang khas pada mitokondria. Pola swelling dipengaruhi oleh berbagai faktor seperti komposisi bufer, kadar t-BuOOH, jumlah bufer isolasi dan protein mitokondria serta temperatur inkubasi. Swelling dapat dihambat sebesar $85 \pm 3 \%$ oleh kurkumin $2.50 \mu$ M. Pada kadar rendah (1.25 $\mu M)$ dan tinggi (5.00 $\mu M)$, efek proteksi kurkumin terhadap swelling berkurang (berturut-turut $41 \pm 3 \%$ and $77 \pm 6 \%$ ). Swelling dapat terjadi akibat terbukanya mitochondrial transition pore dan dapat merupakan petunjuk awal dari proses kematian sel. Efek inhibisi kurkumin terhadap swelling mitokondria yang diinduksi oleh t-BuOOH diduga disebabkan karena efek antioksidannya. (Med J Indones 2006; 15:131-6)
\end{abstract}

\begin{abstract}
Liver diseases have been a medical problem which is difficult to manage. Some of the problems in the treatment of these diseases lie in the lack of reliable drug available. Curcumin, an active ingredient of the rhizomes of plant Curcuma has been investigated in the treatment of various disorders incuding liver diseases. The therapeutic effects of curcumin on liver diseases have been thought to be associated to its antioxidative properties. In the present study, we investigated the effects of curcumin on mitochondrial swelling in vitro induced by tert-butylhydroperoxide $(t-B u O O H)$. Liver mitochondria were homogeneously isolated from Sprague-Dawley rats (the relative specific activity of succinate dehydrogenase was $35.73 \pm 2.78$ ). Addition of $90 \mu \mathrm{M}$ of $t$-BuOOH caused a typical 2-phase swelling of the mitochondria. The pattern of swelling was influenced by various factors such as buffer composition, concentrations of $t-\mathrm{BuOOH}$, amount of isolation buffer and mitochondrial proteins and incubation temperature.The swelling could be reduced by as much as $85 \pm 3 \%$ by $2.50 \mu M$ of curcumin. At lower $(1.25 \mu M)$ or higher $(5.00 \mu M)$ concentrations, the protection against swelling by curcumin were less effective (respectively were $41 \pm 3 \%$ and $77 \pm 6 \%$ ). Swelling might occur due to the opening of mitochondrial transition pore and could be an initial indication in the cascade process leading to cell death. The inhibition of t-BuOOH-induced mitochondrial swelling by curcumin might be because of the antioxidant effects of the compound. (Med J Indones 2006; 15:131-6)
\end{abstract}

Keywords: mitochondria, swelling, tert-butylhydroperoxide, curcumin

Liver diseases have been endemic in Asian countries including Indonesia. Currently there is no specific therapy available in the treatment of hepatitis and cirrhosis. Previous drugs claimed to be beneficial for liver diseases have been withdrawn from the market because of lack of proven efficacy. ${ }^{1}$ In order to curb the problem various efforts have been put in to obtain

Department of Pharmacology \& Therapeutics, Faculty of Medicine University of Indonesia, Jakarta, Indonesia reliable remedies for the diseases. One among those is empirical approach, i.e. to explore the possible use of potential natural ingredient from certain herbs like curcuma rhizomes.

A large body of evidence has indicated the pivotal role of mitochondria in cellular life and death. ${ }^{2}$ Mitochondrial dysfunction has been thought to be involved in the induction of the programmed cell death. $^{3}$ Mitochondrial dysfunction was thought to begin with the formation of permeability transition pore (PTP) at the level of the contact site, between the 
inner and the outer mitochondrial membranes. PTP opening induces swelling, collapse of mitochondrial membrane potential, inhibition of ATP production and cellular death. Curcumin, an active pigment of rhizomes of Curcuma plants has been demonstrated to have many pharmacological effects such as antiinflammation, antioxidant, anticarcinogenic, antiinfectious and hypocholesterolemic activities. ${ }^{4}$ Curcumin has been shown to be protective against oxidant-induced biochemical dysfunction of mitochondrial preparation isolated from the rat liver. ${ }^{14}$ In the present study, we investigated the effect of curcumin against mitochondrial dysfunction, i.e. swelling induced by t-butylhydroperoxide $(\mathrm{t}-\mathrm{BuOOH})$.

\section{METHODS}

\section{Materials}

Curcumin, EGTA, Trizma $\mathrm{HCl}$, bovine serum albumin (BSA), t-butylhydroperoxide $(\mathrm{t}-\mathrm{BuOOH})$, rotenone were purchased from Sigma Chemical Co., USA. Sucrose, Folin-Ciocalteu's phenol reagent, 2-6 dichlorophenol indophenol (DCPIP), sodium dodecyl sulphate and other salts were from E. Merck, Darmstadt, Germany.

\section{Isolation of mitochondria}

Rat liver mitochondria were isolated according to the method as described by Towers et $\mathrm{al}^{5}$ with minor modification. Briefly, male adult rats of SpragueDawley strain (age 3-4 months, weight 160-180 g, each) were sacrified by cervical dislocation. The livers were excised, weighed and homogenized in a Potter Elvehjem glass homogenizer. A $10 \%(w / v)$ homogenate was made in ice cold SET-34 solution containing $0.34 \mathrm{M}$ sucrose, $1 \mathrm{mM}$ EGTA, $2 \mathrm{mM}$ Tris$\mathrm{HCl}, \mathrm{pH} 7.4$ and $0.05 \%$ BSA (w/v). After centrifugation at low speed $(1000 \mathrm{~g})$ to discard nuclei and cellular debris, the supernatant was further centrifuged at $10,000 \mathrm{~g}$ and $8,000 \mathrm{~g}$, respectively, to obtain the mitochondrial fraction. The mitochondrial fraction was resuspended in SET-34 solution without BSA in a concentration of $50 \mathrm{mg}$ protein $/ \mathrm{ml}$. The procedure yielded mitochondrial protein of $20 \mathrm{mg} / \mathrm{g}$ of liver. Inner mitochondrial enzyme marker, succinate dehydrogenase, was measured as described by Evans. ${ }^{6}$ The protein content was determined as described by Peterson, ${ }^{7}$ using BSA as standard.

\section{Mitochondrial swelling}

Swelling of mitochondria was carried out by measuring the changes of volume of the mitochondrial matrix as shown by the decrease in optical density at $520 \mathrm{~nm}$. Freshly prepared mitochondria of 0.3-0.4 mg protein/ml was diluted with $0.175 \mathrm{M} \mathrm{KCl}, 0.025 \mathrm{M}$ Tris $\mathrm{HCl}, \mathrm{pH} 7.4$ in a total volume of $1.4 \mathrm{ml}$. Thereafter, the change of aborbance at an interval of 15 seconds was followed for $5 \mathrm{~min}$ at room temperature. ${ }^{8}$

Percentage of protection of curcumin against swelling induced by $\mathrm{t}-\mathrm{BuOOH}$ was calculated by the formula as described below:

$$
\% \text { of protection }: \frac{\Delta \mathrm{Ac}-\Delta \mathrm{A}}{\Delta \mathrm{A} \mathrm{t}-\mathrm{BuOOH}-\Delta \mathrm{A}}
$$

$\Delta \mathrm{Ac}=\Delta$ absorbance in control group after 5 min reading $\Delta \mathrm{A} \mathrm{t}-\mathrm{BuOOH}=\Delta$ absorbance in the group with $\mathrm{t}-\mathrm{BuOOH}$ after 5 min reading

$\Delta \mathrm{A}=\Delta$ absorbance in the curcumin group after 5 min reading

\section{Statistical analysis}

The degree of normality and variant homogeneity of the data were tested by Kolmogorov-Smirnov (K-S test for rankable scores) and F test. ${ }^{9}$ Since the data obtained showed a normal and homogeneous distribution, they were analyzed using the related one-way ANOVA followed by Tukey method at a significance level of $\alpha=0.05$.

\section{RESULTS}

\section{Extent of purification of the isolated mitochondrial preparation}

The mitochondrial preparation was homogeneously purified as shown by the high relative specific activity (RSA) of succinate dehydrogenase of $35.73 \pm 2.78$ (Table 1); the mitochondrial protein yield was $19.96 \pm$ $1.95 \mathrm{mg} / \mathrm{g}$ wet liver.

\section{Factors influencing mitochondrial swelling}

The pattern of mitochondrial swelling induced by $\mathrm{t}-\mathrm{BuOOH}$ is subject to several conditions, i.e.: composition of incubation medium, concentration of t-BuOOH, amount of SET-34, amount of mitochondrial protein, phosphate buffer, temperature of incubation and in vitro aging of the mitochondrial preparation. 


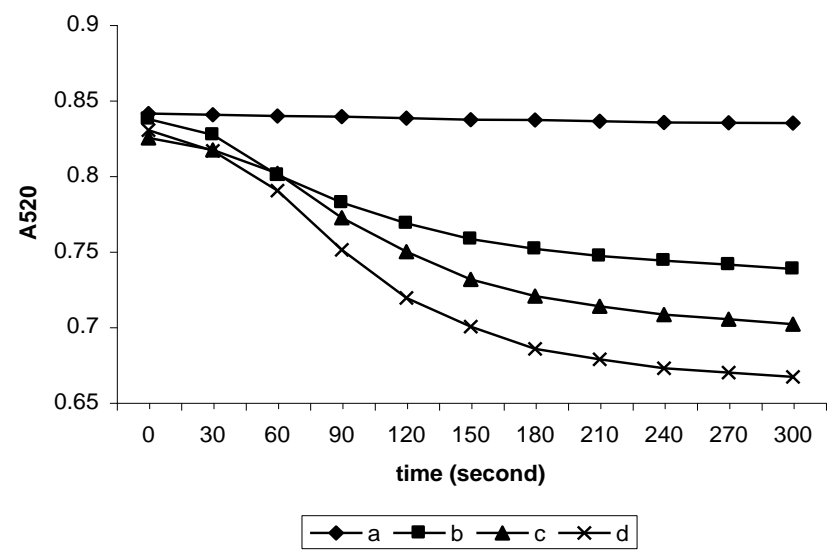

Figure 1. depicts the effects of composition of incubation medium. Larger swelling was obtained when the concentration of $\mathrm{KCl}$ and Tris buffer was changed from $\mathrm{KCl} 0.125 \mathrm{M}$ - Tris $\mathrm{HCl} 0.025$ $\mathrm{M}$ to $\mathrm{KCl} 0.175 \mathrm{M}$ - Tris $\mathrm{HCl} 0.025 \mathrm{M}$.

Swelling of the mitochondrial preparation was dependent on the concentration of $\mathrm{t}-\mathrm{BuOOH}$ and showed a biphasic pattern (Figure 2). Large swelling was obtained when the mitochondrial fraction was induced by a concentration of t-BuOOH of $90 \mu \mathrm{M}$. Swelling occurred rapidly at the first phase which lasted for 90 min and was followed by a relatively slower phase.

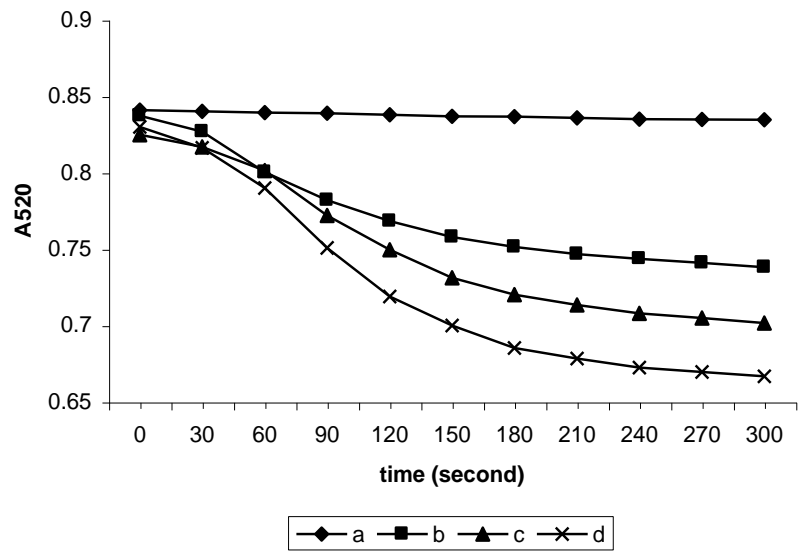

Figure 2. The effects of different concentration of $t-\mathrm{BuOOH}$ on pattern of mitochondrial swelling a, control; $b, c, d$, with $t-\mathrm{BuOOH}$ of $60 \mu M, 75 \mu M$ and $90 \mu M$ respectively

The amount of SET-34 added in the preparation of mitochondrial suspension also determined the pattern of swelling. The optimal SET-34 added was aproximately as much as twice the volume of the mitochondrial preparation (Figure 3). Addition of SET-34 medium less that the recommended volume mentioned above resulted in premature swelling before $\mathrm{t}-\mathrm{BuOOH}$ induction, whereas at larger medium addition, swelling failed to occur despite induction by $\mathrm{t}-\mathrm{BuOOH}$.

Swelling phenomenon was critically dependent on the amount of mitochondrial protein in the assay. In our study, the optimal absorbance was obtained when the mitochondrial protein was 2-3 ug. The curve remained stable during $5 \mathrm{~min}$ incubation and then was followed by deflection giving the typical swelling curve upon induction by t-BuOOH (Fig. not shown).

Use of phosphate buffer should also be put into consideration as a larger volume of buffer to resuspend the curcumin also produced a premature swelling of the mitochondria (Fig. not shown).

Finally, changing the temperature of incubation of the mitochondrial preparation would give different pattern of swelling (Fig. 3). Incubation on ice for 15 min rendered shrinkage of the organelles and addition of $\mathrm{KCl} 0.175 \mathrm{M}-$ Tris $\mathrm{HCl} 0.025 \mathrm{M}$ resulted in large swelling. Whereas, incubation at room temperature for $15 \mathrm{~min}$, caused mitochondrial lysis presumably due to rapid in vitro aging. To obtain the optimal result, the mitochondrial preparation should always be kept on ice and swelling experiment must be immediately executed at room temperature in which all added solutions were kept at room temperature.

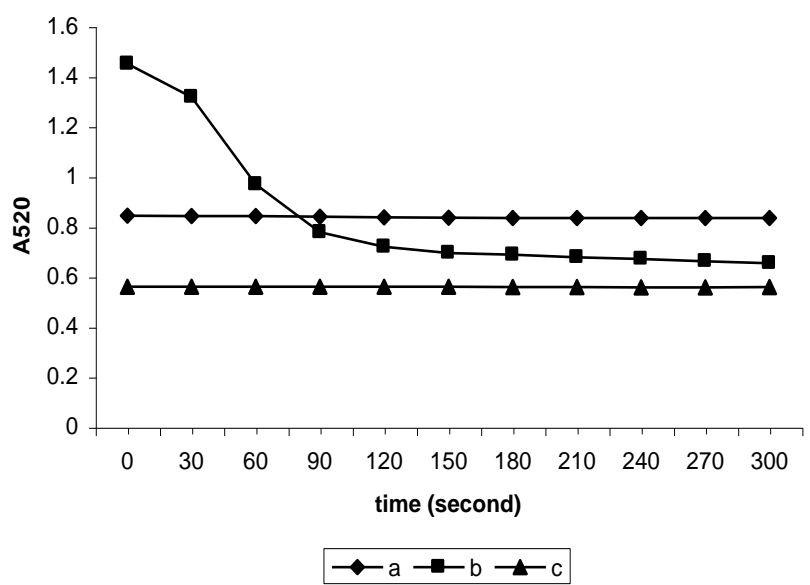

Figure 3. The effects of incubation temperature on pattern of mitochondrial swelling. Swelling was measured immediately after incubation of the mitochondrial preparation with $t-\mathrm{BuOOH}$ $90 \mu M$ at room temperature (a); after incubation for 15 min at $O^{\circ} \mathrm{C}(b)$ and after incubation for $15 \mathrm{~min}$ at room temperature $(c)$ 


\section{The protective effects of curcumin against mitochondrial swelling induced by $\mathrm{t}-\mathrm{BuOOH}$}

Table IV and Fig. 4 show large swelling of the mitochondrial preparation induced by t-BuOOH of 90 $\mu \mathrm{M}$ (ID group, $0 \%$ protection vs. control, $\mathrm{K}$ group, $100 \%)$. Incubation without curcumin (IK group) and groups with curcumin of low and moderate doses (IK $1.25 \mu \mathrm{M}$ and $2.50 \mathrm{uM}$ ) did not cause swelling, whereas at the highest dose (IK $5.00 \mu \mathrm{M}$ ), swelling was presumably beginning to occur. Curcumin of moderate dose (ID 2.50) could substantially reduce swelling $(84.74 \pm 3.22 \%)$, while at lower (IK $1.25 \mathrm{uM}$ ) and higher (IK $5.00 \mathrm{uM}$ ) doses the protective effects were less (40.46 $\pm 3.43 \%$ and $77.26 \pm 5.51 \%$, respectively).

Table 1. Protein content of homogenate and mitochondrial fraction

\begin{tabular}{lcc}
\hline \multirow{1}{*}{ Fraction } & \multicolumn{2}{c}{$\begin{array}{c}\text { Protein content } \\
(\mathrm{X} \pm \mathrm{SD})\end{array}$} \\
\cline { 2 - 3 } & $\mathrm{mg} / \mathrm{g}$ liver & $\%$ homogenate \\
\hline Homogenate & $230 \pm 23$ & $100 \pm 0$ \\
Mitochondria & $20 \pm 2$ & $8.67 \pm 0.30$ \\
\hline
\end{tabular}

Data are from 5 experiments

Table 2. Specific activity (SA) and relative specific activity (RSA) of succinate dehydrogenase of rat liver mitochondria

\begin{tabular}{cccc}
\hline \multirow{2}{*}{ Fraction } & Protein & \multicolumn{2}{c}{$\mathrm{SDH}(\mathrm{X} \pm \mathrm{SD})$} \\
\cline { 3 - 4 } & $\begin{array}{c}\mathrm{X} \pm \mathrm{SD}) \\
\% \text { of } \\
\text { homogenate }\end{array}$ & $\begin{array}{c}\mathrm{SA} \\
(\mathrm{nmol} / \mathrm{min} / \mathrm{mg}\end{array}$ & $\mathrm{RSA}$ \\
protein & \\
\hline Homogenate & $100 \pm 0$ & $8.84 \pm 0.71$ & \\
Mitochondria & $8.67 \pm 0.30$ & $27.35 \pm 2.58$ & $35.73 \pm 2.78$ \\
\hline
\end{tabular}

RSA is defined as the percentage of total homogenate activity present in mitochondrial fraction divided by the percentage of total protein present in that fraction.

Data are from 5 experiments

\section{DISCUSSION}

Rhizomes of curcuma plants have been traditionally used for centuries in the treatment of liver diseases in many Asian countries. The biologically active substance of curcuma, i.e.: curcumin, has been investigated in various models of experimental liver diseases.

Oxidative stress has been shown to play an important role in the pathological mechanism of diseases and the hepatoprotective action of curcumin is associated with its antioxidant properties. Although the hepatoprotective efects of curcumin have been reported in vitro and in vivo studies, ${ }^{10-13}$ studies of its effects on subcellular organelles have been few, if any. In studying the pathology of diseases, mitochondria has been proposed to play a fundamental role in cell death.2 In the previous report, ${ }^{14}$ we found that curcumin was partially protective in preserving the mitochondrial enzymes activity and GSH content upon exposure to t-BuOOH.

Damage of mitochondrial membrane due to lipid peroxidation and protein cross linking ${ }^{15}$ caused an increased in the inner membrane permeability leading to transmembrane collapse and cessation of ATP production. One among several methods commonly used in the evaluation of the inner mitochondrial membrane permeability is the swelling study. ${ }^{16}$ Swelling of the mitochondria is esentially an osmotic process that results from net solute and water diffusion towards the matrix. ${ }^{17}$ Swelling may occur in two mechanisms; the first, energy-dependent type of swelling which occurs without loss of energy other than that spent for the process of monovalent $\left(\mathrm{K}^{+}\right.$in particular) accumulation. In this mode of swelling, ATP can still be produced. The second type of swelling is called low energy swelling, which is caused by opening of the mitochondrial permeability transition pore (MTP), in which passive diffusion of solutes and water down their concentration gradient following a decrease of the permeability barrier. Shrinkage and volume recovery are only posible when the species responsible for swelling can be extruded by endogenous transport pathways.

The production, pattern and magnitude of swelling are determined by various factors. Hypotonic swelling in vitro is influenced by the composition of the medium and substrate addition such as succinate, phosphate, magnesium ions, AMP content, dinitrophenol, etc. ${ }^{18}$ Ionic strength such as molarity of salt used $(\mathrm{KCl})$ should also be put into consideration. ${ }^{16}$ Our present results also showed similar phenomenon. Pattern of mitochondrial swelling could be modified by changing the buffer medium, the amount of buffer protein and the concentration of t-BuOOH. The concentration of $\mathrm{t}-\mathrm{BuOOH}$ used in our study, $90 \mu \mathrm{M}$, is a little bit higher that that of Kakkar et al ${ }^{19}$ of 75 $\mu \mathrm{M}$. The amount of reactive oxygen species was not quantified in our study. Similarly the roles played by individual factors such as the composition of medium, etc. in optimalizing swelling were not elaborated since they were beyond the objectives of the study. 
In the present study, an exogenous oxidant administered to the isolated mitochondrial preparation caused mitochondrial swelling. This type of swelling is thought to occur via opening of the MTP. It is presumed that $\mathrm{t}-\mathrm{BuOOH}$ causes oxidation, lipid peroxidation or protein cross linking of the MTP that result in pore opening. ${ }^{20}$ The previous notion that $\mathrm{t}$ $\mathrm{BuOOH}$ induced permeability transition due to oxidation of pyridine nuckleotides ${ }^{21}$ was refuted by novel studies. ${ }^{22}$ Our results are in agreement with that obtained by Morin et al, ${ }^{23}$ which showed that $\mathrm{t}-\mathrm{BuOOH}$ induced mitochondrial swelling on deenergized mitochondria. These results suggest that t-BuOOH acts specifically at the MTP.

According to Kakkar et al, ${ }^{19} \mathrm{t}$-BuOOH induced swelling of mitochondria was accounted for by $\mathrm{Fe}^{2+}$ in the first initial rapid phase and $\mathrm{Ca}^{2+}$ - related processes in the second. Mitochondrial swelling by t-BuOOH was decreased by curcumin of $2.5 \mu \mathrm{M}$, by as much as $85 \%$. Curcumin appeared to work by scavenging the hydroxyl radical produced by t-BuOOH. According to Wright $^{24}$ the $\mathrm{OH}$ bonding is the most important region of curcumin as antioxidant. Both phases of swelling are inhibited by curcumin. In the first phase, curcumin acts as a $\mathrm{Fe}^{2+}$ chelator, ${ }^{19,25}$ which prevents the generation of hydroxyl radicals via Fenton reaction. In this respect, curcumin by virtue of its lipophilic nature will be inserted into membrane and behaves as $\mathrm{Fe}^{2+}$ chelator. In the second phase, curcumin inhibits $\mathrm{Ca}^{2+}$ efflux by scavenging the hydroxyl radicals.

Several studies demonstrated the association between swelling and mitochondrial permeability transition., ${ }^{3,26,27}$ It has also been used to detect the opening of mitochondrial permeability pore. ${ }^{28,29}$ In the present study, we did not investigate the effects of cyclosporine A, a specific inhibitor of mitochondrial permeability transition, in comparison with curcumin against swelling. Nevertheless, the protective effects of curcumin against mitochondrial swelling induced by $\mathrm{t}-\mathrm{BuOOH}$ might explain the possible beneficial effects of curcumin in the treatment of liver diseases.

\section{Acknowledgement}

This study was partially supported by the URGE Project Batch III.

\section{REFERENCES}

1. Government Regulation (Peraturan pemerintah no.275 a/MenKes/SK/XI/1989).
2. Kroemer G, Dellaporto B, Resche-Rigon M. The mitochondrial death/life regulator in apoptosis and necrosis. Ann Rev Physiol 1998; 60: 619.42.

3. Susin SA, Zamzami N, Kroemer G. The cell biology of apoptosis: evidence for the implication of mitochondria. Apoptosis 1996; 4: 231-42.

4. Ammon HPT, Wahl MA. Pharmacology of curcuma longa. Planta Medica 1991; 57: 1-7.

5. Towers NR, Dixon H, Kellerman GM, Linnane AW. Biogenesis of mitochondria. The sensitivity of rat liver mitochondria to antibiotics; a phylogenetics difference between a mammalian system and yeast. Anal Biochem Biophys 1972; 151: 361-9.

6. Evans HW. Preparation and characterization of mammalian plasma membranes. In: Work TS, Work E, editors. Laboratory techniques in biochemistry and molecular biology. Elsevier/North Holland 1978; pp. 93-176.

7. Peterson GL. A simplication of the protein assay method of Lowry et al, which is more generally applicable. Anal Biochem 1997; 83: 346-56.

8. Visarius TM, Stucki JW, Lanterburg BH. Stimulation o respiration by methylene blue in rat liver mitochondria FEBS Lett 1997; 412: 157-60.

9. Meddis R. Statistical handbook for non-statistians. Mc Graw-Hill 1975, pp. 65-124.

10. Suyatna FD, Gan S, Siswoyo K, Asikin N, Rosmiati H, Pringgoutomo S. The effects of curcuma against paracetamol-induced liver damage in rats. Med J Univ Indonesia 1992; 1: 20-34.

11. Kiso Y, Suzuki Y, Watanabe N, Oshima Y, Hikino H. Antihepatoxic principles of curcuma longa rhizomes. Planta Med 1983; 49: 185-7.

12. Chuang S, Cheng A, Lin J, Kuo M. Inhibition by curcumin of dietylnitrosamine-induced hepatic hyperplasia, inflammation, cellular geneproducts and cell-cycle related proteins in rats. Food Chem Toxicol 2000; 38: 991-5.

13. Park EJ, Jeon CH, Ko G, Kim J, Sohn DH. Protective effects of curcumin in rat injury induced by carbon tetrachloride. J Pharm Pharmacol 2000; 129: 231-4.

14. Suyatna FD, Djohan R, Nafrialdi, Suherman SK. The antioxidant effects of curcumin on rat liver mitochondrial dysfunction induced by tert-butylhydroperoxide. J Ecophysiol Occup Hlth 2004; 4: 145-51.

15. Gadelha FR, Thomson L, Fagian MM, Costa ADT, Radi $\mathrm{R}$, Vercesi AE. $\mathrm{Ca}^{2+}$-independent permeabilization of the inner mitochondrial membrane by peroxynitrite is mediated by membrane protein thiol cross-linking and lipid peroxidation. Anal Biochem Biophys 1997; 345: 243-50.

16. Massari S, Frigeri L, Azzone GF. Permeability to water, dimension of surface and structural changes during swelling in rat liver mitochondria. J Membrane Biol 1972; 9: 57-70.

17. Bernardi P, Scorrano L, Colona R, Petronilli V, Di Lisa F. Mitochondria and cell death. Mechanistic aspects and methodological and issues. Eur J Biochem 1999; 264: 687-701.

18. Lipsett MN, Corwin LM. Studies on stability of rat liver mitochondria. Role of oxidative phosphorylation in swelling. J Biol Chem 1959; 234: 2448-52. 
19. Kakkar P, Mehrotra S, Viswanathan PN. tBHP induced in vitro swelling of rat liver mitochondria. Mol Cell Biochem 1996; 154: 39-45.

20. Kowaltowski AJ, Castilho RF, Grijalba MT, Bechara EJ, Vercesi AE. Effect of inorganic phosphate concentration on the nature of inner mitochondrial membrane alterations mediated by $\mathrm{Ca}^{2+}$ ions. A proposed model for phosphate stimulated lipid peroxidation. J Biol Chem 1996; 271:2929-34.

21. Gunter TE, Pfeiffer DR. Mechanisms by which mitochondria transport calcium. Am J Physiol 1990; 258: C755-C786.

22. Reef DJ, Savage MK. Influence of metabolic inhibitors on mitochondrial permeability transition and flutathione status. Biochim. Biophys Acta 1995; 1271: 43-50.

23. Morin D, Barthelemy S, Zini R, Labidalle S, Tillement JP. Curcumin induces the mitochondrial permeability transition pore mediated by membrane protein thiol oxidation. FEBS Lett 2001; 495: 131-6.
24. Wright JS. Predicting the antioxidant activity of curcumin and curcuminoids. J Mol Struct (Theochem) 2002; 591: 207-17.

25. Tonnesen HH, Smistad G, Agren T, Karlsen J. Studies on curcumin and curcuminoids. XXIII: Effects of curcumin on liposomal lipid peroxidation. Int J Pharm 1993; 90: 221-8.

26. Petit PX, Goubern M, Diolez P, Susin SA, Zamzami N, Kroemer G. Disruption of outer mitochondrial membrane as a result of large amplitude swelling: the impact of irreversible permeability transition. FEBS Lett 1998; 426: 111-6.

27. Zoratti M, Szabo I. The mitochondrial permeability transsition. Biochim. Biophys. Acta 1995; 1241: 139-176.

28. Reed DJ, Savage MK. Influence of metabolic inhibitors on mitochondrial permeability transition and glutathione status. Biochim. Biophys. Acta 1995; 1271: 43-50.

29. Bernardi $P$. The permeability transition pore. History and perspective of a cyclosporin A - sensitive mitochondrial channel. Prog Cell Res 1995; 5: 119-23. 